\title{
POSSIBLE WAYS OF IMPROVING RAILWAY OPERATION AND INFRASTRUCTURE IN AREA BETWEEN DĚČÍN AND RUMBURK
}

\author{
Pavel Purkart ${ }^{a *}$, David Vodák ${ }^{a}$, Tomáš Hoření ${ }^{b}$, Tomáš Javořík $^{a}$ \\ ${ }^{a}$ Department of Transportation Systems, CTU in Prague Faculty of Transportation Sciences, Prague, Czech \\ Republic \\ ${ }^{b}$ METROPROJEKT Praha a.s., Prague, Czech Republic, graduate of CTU in Prague Faculty of Transportation \\ Sciences, Prague, Czech Republic \\ * corresponding author: purkapav@fd.cvut.cz
}

\begin{abstract}
This paper is dealing with improving the railway transport on axis Děčín - Rumburk. This journey can be undertaken in two possible ways (as an interstate one or an international one through Germany), however the connections between trains are limited (especially problematic is the Rumburk junction, where the connection would be desired). The aim of this paper is to improve the connections in the whole area, in order to reach the maximal effectiveness of a railway passenger transport.
\end{abstract}

KEYWORDS: Rumburk, Děčín, Ústecký region, railway transport, periodic timetable, node, service conception, travel times reduction.

\section{INTRODUCTION AND GOALS}

\subsection{RESEARCHED AREA}

The researched area is located in Ústecký region near borders with Federal Republic of Germany, particularly in the area between towns Děčín and Rumburk (mainly north and south from Děčín). The most significant towns in the area are Děčín, Česká Kamenice, Rumburk, Varndorf and Šluknov. Whole area is also very attractive for tourists - some railway lines are located very close to the borders of national park České Švýcarsko.

Following railway lines can be included into the researched area (numbers according to the timetable 2016/2017 [1], see Fig. 1]:

- railway line 080 in the section Česká Lípa - Jedlová,

- railway line 081 Děčín - Benešov nad Ploučnicí Jedlová - Rumburk

- railway line 083 Děčín - Bad Schandau - Dolní Poustevna - Šluknov - Rumburk,

- railway line 084 Rumburk - Panský - Mikulášovice with bypass Panský - Krásná Lípa (- Rumburk),

- railway line 086 in the section Benešov nad Ploučnicí - Česká Lípa,

- railway line 089 Liberec - Zittau - Rybniště,

- railway line Rumburk - Jiř́kov - Ebersbach without regular passenger transport.

\subsection{REASONS BEHIND SELECTING THE RESEARCHED AREA}

Main reason for selection of this area was restoration of operation on border crossing Dolní Pustevna Sebnitz in the year 2014. This brought certain changes in service conception in the area. Unfortunately, those changes also caused some connection between trains in the station Rumburk to disconnect. Despite the fact, that some conceptual changes were made after the year 2014, current situation is still not optimal and that is why the problem is still topical.

After the opening of border crossing Dolní Pustevna - Sebnitz, most of the trains in Rumburk were concentrated to the time period around minute X.30 [1], but it did not created periodic timetable node, because many trains remained without mutual connection due to infrastructural issues. It is also hardly possible to consider it partial periodic timetable node, because connections were actually interrupted, rather than made functional.

Change in passenger service conception came with the activation of railway station Markvartice, where regular crossing of the passenger trains was moved. Paradoxically, this made the creation of connections in the railway station Rumburk even more matter of distant future. This step creates really close sequence of trains Děčín - Jedlová - Rumburk and Děčcín Česká Lípa in the section Děčín hl.n. - Benešov nad Ploučnicí that disrupts periodic sequence of trains in this section. Therefore, effect of implemented conceptual changes is questionable. If the goal was to disconnect links to EC trains in the station Děčín hl. n. (due to their limited reliability - more frequent and higher delays, compared with average values), it is possible to understand those changes. On the other hand, it is also possible to see those actions as a form of resignation to solve problems where they appear.

Formulation of those reasons made the team of authors to reflect on this issue and they attempted to find a solution. This solution should solve all the problems and also offer attractive pass through the railway 


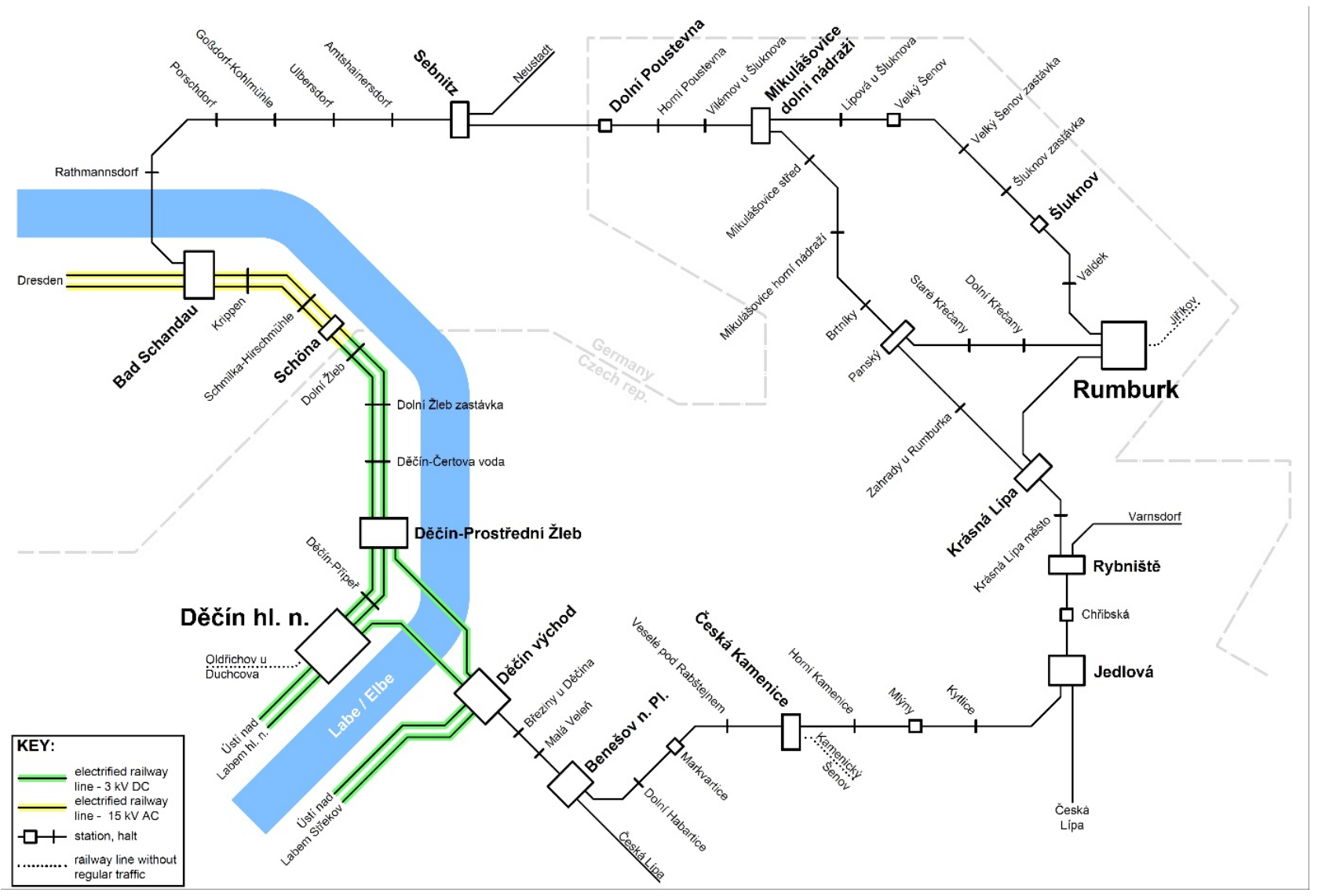

FIGURE 1. Diagram of railway network in the researched area.

junction Rumburk for the passengers. Importance of this pass through is regional, but still important.

\section{UNDERSTANDING AND SOLVING THE ISSUE}

Solving of the issue was performed in several steps, as it is usual in transport planning:

- detailed analysis of the commuting in the researched area in the relation to the railway transport and its possibilities,

- specifying the principles of new service conception and important construction points of the periodic timetable

- detailed design of service conception,

- specifying necessary infrastructural changes to reach service conception

\section{Solution of the issue}

\subsection{Summary of FACTS ABOUt COMMUting IN THE RESEARCHED AREA}

To asses meaningfulness of transit through the railway junction Rumburk it is necessary to evaluate regular commuting in the researched area first. To do so, data from the National counting of inhabitants, houses and flats 2011 [2], has been used. The evaluation of data shows following:
- from the regional point of view, both commuting to Děčín and Rumburk are important. The closer to Děčín or Rumburk a populated area is, the more people are commuting,

- part of inhabitants also commutes to smaller cities such as Česká Kamenice, Benešov nad Ploučnicí, Šluknov and etc.

- very significant is commuting to the regional capital Ústí nad Labem, but commuting to another regional capital - Liberec, has also been found in a part of the area (railway line 038),

- many inhabitants from the Rumburk area are commuting to Varnsdorf and we also cannot omit the influence of Česká Lípa,

- it is appropriate to ensure availability of Prague for whole area,

- breaking branches of railway lines 081, 083 in Rumburk does not influence major numbers of passengers (breaking somewhere else can have worse consequences), but their connection may bring significant improvement of transport in the whole area (direction to/from Varnsdorf) of transport to larger cities - that makes this idea meaningful.

It is crucial to identify transport relations, which would pass through this junction, to defend creation of connections in Rumburk. As it has been already 
mentioned - good connections and fast pass through station Rumburk may attract many local inhabitants. Significant interactions in relations Šluknov - Varnsdorf, Velký Šenov - Varnsdorf, Mikulášovice - Varnsdorf, were identified in regular commuting. Another relations, which can be considered as long distance commuting, were also identified. Improving of pass through Rumburk could have positive effect also on these relations. There is a potential of $\mathbf{2 5 0}-$ 300 regular commuters in villages located only near railway lines (with acceptable walking distance from village to railway line), this number is sufficient enough to take this into consideration. However it is necessary to prefer more important transport relations in order to not create a negative impact on them.

\subsection{Design OF THE NEW SERVICE CONCEPTION}

Design of the new service conception was made according to all the periodical timetable rules. The most important passenger line, which should eliminate all problems in the station Rumburk, is new passenger line Děčín - Benešov nad Ploučnicí - Jedlová Rumburk - Dolní Poustevna - Sebnitz - Bad Schandau - Děčín.

It is proposed to connect branches of both lines Děčín - Rumburk (an interstate one and an international one through Germany) and create pass through model in the station Rumburk.

Basic interval is 120 minutes.

Interval is shortened to 60 minutes in the section Děčín - Česká Kamenice (- Jedlová). Another section with interval 60 minutes is Děčín - Schöna. Combination of the new line and long-distance trains in the section Jedlová - Rumburk - Šluknov - Dolní Poustevna also creates interval of 60 minutes (long-distance trains in the section Šluknov - Dolní Poustevna are operated only on work days).

It is crucial to establish important line construction points for periodical timetable. Key connection in the station Děčín is connection to EC trains from/to Prague (node in the minute X.00). Extra trains should be extended to/from ústí nad Labem in the time of afternoon rush hours, as a fast connection to the regional capital (EC trains are operated only in 120 minutes interval). These trains should be operated with minimum stoppings (in the section Děčín - Ústí nad Labem).

Other important construction point is in the station Jedlová in minute X.00 and in the station Rumburk in minute X.30 (because of important connections).

Second line branch from Děčín, in direction Bad Schandau, arrives to Děčín in the minute X.00. There are important connections to long-distance trains Děčín - Ústí nad Labem - Lovosice - Praha and regional trains Děčín - Most. Both railway line branches, which are entering the junction have the connection to/from Prague ensured. In one case the new connection is faster than the one in current timetable.

There are 4 vehicles necessary to provide base interval of 120 minutes (without reserve). Those trains are also capable of ensuring extra trains Děčín - Schöna. Another two vehicles are necessary for extra rush hour trains Ústí nad Labem - Děčín - Česká Kamenice Jedlová (without reserve).

Together with designing new circular line, service conception of the lines in the area was also modified. This includes long-distance trains Ústí nad Labem Liberec and Kolín - Rumburk - Šluknov and regional trains Děčín - Česká Lípa, Jedlová - Česká Lípa or Rybniště - Varnsdorf - Liberec. Also new routes of Mikulášovice dolní nádraží - Panský - Rumburk Ebersbach trains were designed, in case of shortening intervals (Mikulášovice dolní nádraží - Panský - Rumburk) or restoring the regular passenger operation (Rumburk - Ebersbach). And finally routes for a pair of seasonal tourist trains Děčín - Jedlová Krásná Lípa - Panský - Mikulášovice dolní nádraží has also been found. Complex design of whole system is summarized in the network diagram (Fig. 2).

\subsection{INFRASTRUCTURAL CHANGES NECESSARY FOR THE NEW SERVICE CONCEPTION}

Following infrastructure modifications are necessary for the application of designed timetable:

- reconstruction of the railway station Rumburk, so it can handle the operation of periodic timetable node at minute X.30,

- reducing the travel times at the Benešov nad Ploučnicí - Rumburk branch (reducing time by 2 or 3 minutes, in some parts of the branch reduction could be reached by using modern vehicles)

- reducing the travel times at the Rumburk - Panský Mikulášovice dolní nádraží and Rumburk - Šluknov - Mikulášovice dolní nádraží branches (reducing time by 5 minutes),

- reducing the travel times in the section Jedlová - Česká Lípa to the systematical travel time 30 minutes,

- reducing the travel times of long distance trains in the section Bakov nad Jizerou - Česká Lípa by 10 minutes,

- consider necessary modifications of the stations on railway lines 081 and 083 ,

- in case of implementing a pair of seasonal tourist trains, it is necessary to divide section Panský Mikulášovice into two blocks.

\subsection{RECONSTRUCTION OF THE RAILWAY STATION RUMBURK}

New timetable brings higher requirements for continuity and stability of train operations in the station Rumburk. 


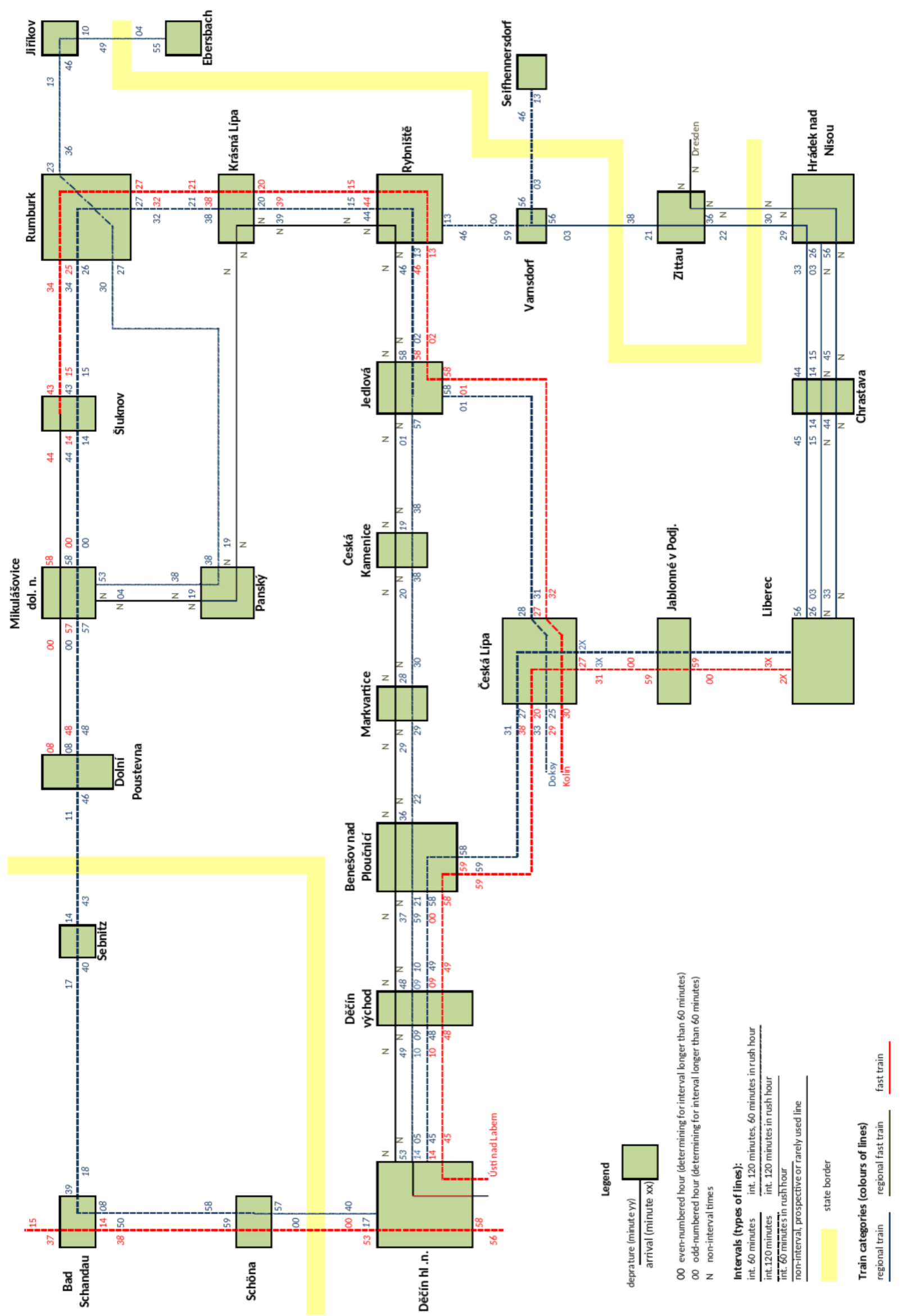

FiguRE 2. Network diagram summarizing proposal of service conception in the researched area. 
Railway station Rumburk is junction for four railway lines from four directions with four neighboring railway stations:

- Krásná Lípa (railway line 081),

- Šluknov (railway line 083),

- Panský (railway line 084 - currently with regular passenger transport only on weekends),

- Jiříkov (currently without regular passenger transport - not numbered).

Designed timetable assumes regular passenger transport on all four railway lines. New timetable is periodical with base intervals 60 or 120 minutes. In addition, full periodical timetable node in the minute X.30 is established in the station Rumburk.

First 3 railway lines above are connected to the western part of the station. Railway line from Jiř́kov is connected to the eastern part of the station. Operation on station head in the western part of the station, where three railway lines are meeting, must be organized very strictly. Main reason is implementing periodical timetable, which causes all arrivals and departures to take place in 10 minutes (6 train routes in 10 minutes). Due to pass through model many routes are colliding in the area of station head.

To ensure the stability of new timetable arrivals of trains from Šluknov, Krásná Lípa a Panský must be performed without collision of routes. Based on all mentioned conditions reconstruction of the railway station Rumburk seems to be the best solution. Reconstruction should include at least tracks configuration, platforms and interlocking [3, 4].

Fig. 3 shows ideal variant of reconstruction.

Western station head allows simultaneous arrival from all three directions at the same time. Longer platform edges are primary located by tracks, where trains to Krásná Lípa and Šluknov are expected to stop. These trains have potential to be longer than trains on other branches. Signal should be placed to the longer edge of platform 3 , in order to coupling train sets. Platform 1 is extra. This configuration of the railway station is crucial for implementation of new service conception.

\subsection{INFRASTRUCTURE MODIFICATIONS FOR REDUCING THE TRAVEL TIMES AND POSSIBLE NEW STOPS}

From infrastructural point of view, this paper offers solution for Benešov nad Ploučnicí - Jedlová - Rumburk - Šluknov - Mikulášovice dolní nádraží section. Upgrading this section is crucial for possible new circular line operation. All modifications are mainly undertaken in the sections between railway stations, railway stations are skipped as a kind of "black box" cutting the travel times is considered, but modifications were not proposed in detail. Main infrastructure modifications are changes in geometrical alignment and establishing speed profile for cant deficiency 130 $\mathrm{mm}$. The longest section with new geometrical alignment has length of $9 \mathrm{~km}$. Steel sleepers with shape of " $\mathrm{Y}$ " are used when there is a new geometrical alignment in a vertical curve, in order to avoid extending subgrade. Limit values of the parameters of geometrical alignment are usually reached while increasing the maximal speed. Maximal/minimal values are reached on exceptionally [4, 5].

Also the reconstruction of signalling and control systems is designed in order to establish device with the third safety level. Safety level is increased on some level crossing as well. Section Rumburk - Šluknov is not considered in interlocking reconstructions, because current interlocking has already been ungraded to the third safety level. Section Šluknov - Mikulášovice d.n. (- Dolní Poustevna) is also skipped, because all railway operation is currently organized according to rule SŽDC D3.

Table 1 shows reached travel times reduction on sections.

Travel times has been calculated in software "Dynamika 1.7.1.", with railcar 843 as a reference vehicle. Some proposed infrastructure modifications are not necessary, because travel times has already been reached in timetable 2016/17, but their introduction may increase the timetable stability.

In order to improve railway transport availability some new stops are proposed - some are designed to replace inappropriate ones and some as completely new. For example: village Horní Habartice is located really close to the railway, so the new stop could be made there. New stop can replace current stop in Veselá pod Rabštejnem, which is located too far away from inhabited area. Establishing new stop RumburkDolní Křečany (Fig. 4) on the railway line 083 could be also interesting, because this stop would be located in the center of inhabited area. Stop Rumburk-Dolní Křečany already exists on the 084 railway line, but second stop could attract more passengers.

\section{Conclusion}

During the problem solving process was managed to prove that the attractive connections between trains in the station Rumburk can be reached without major infrastructure changes and without disconnecting any other important connections. This allowed formation of service conception not only for Děčín and Rumburk areas, but also for parts of Česká Lípa and Liberec areas with overlap to Germany. The result is the paper, which presents a possible way how to increase the effectiveness of a railway passenger transport in researched area.

\section{ACKNOWLEDGEMENTS}

All the facts presented in the article are based on the results of work on project 12X2ZS Railway Network of The Czech Republic and Europe, which is undertaken on CTU Faculty of Transportation Sciences, Department of Transport Systems. 


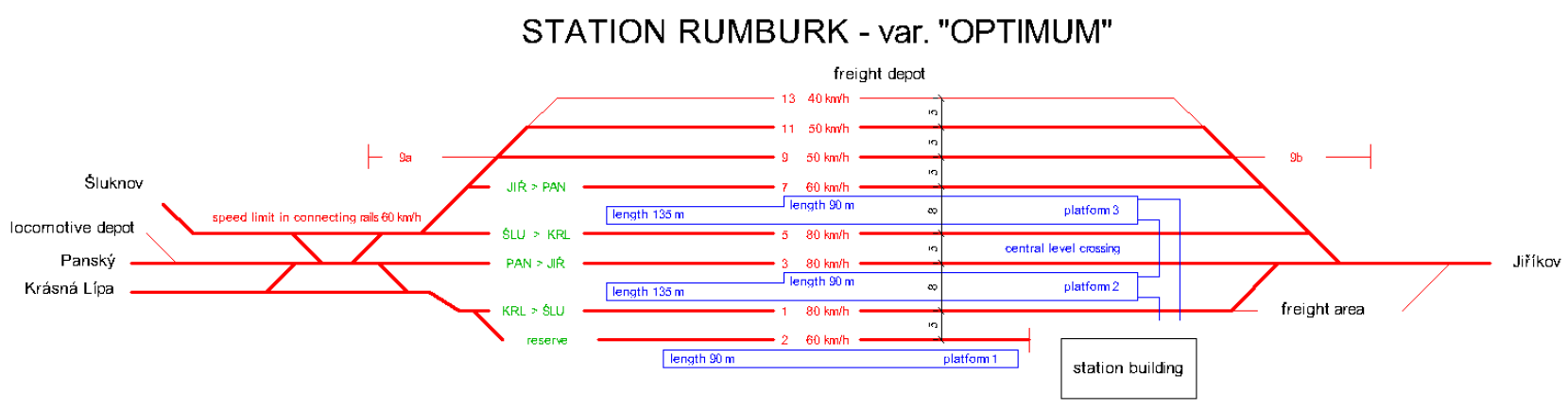

FiguRE 3. Optimal variant of modifications of the railway station Rumburk.

\begin{tabular}{|c|c|c|c|}
\hline \multirow{2}{*}{ section } & length & \multicolumn{2}{|c|}{ Travel time reduction [min] } \\
& & Os & R \\
\hline \hline \multicolumn{4}{|c|}{ section Benešov nad Ploučnicí - Jedlová } \\
\hline Benešov n. Pl. - Markvartice & 5,4 & $-0,5$ & - \\
\hline Markvartice - Ceská Kamenice & 7,9 & -1 & - \\
\hline Česká Kamenice - Jedlová & 15,4 & -2 & - \\
\hline \multicolumn{4}{|c|}{ section Jedlová - Rumburk } \\
\hline Jedlová - Rybniště & 9,3 & $-1,5$ & $-1,5$ \\
\hline Rybniště - Krásná Lípa & 4,8 & $-0,5$ & $-0,5$ \\
\hline Krásná Lípa - Rumburk & 6 & $-0,5$ & $-0,5$ \\
\hline \multicolumn{2}{|c|}{ section Rumburk - Mikulášovice dolní nádraží } \\
\hline Rumburk - Šluknov & 10 & $-2,75$ & -3 \\
\hline Šluknov - Mikulášovice d.n. & 10,6 & $-1,75$ & - \\
\hline
\end{tabular}

TABLE 1. Travel time reduction on individual sections.

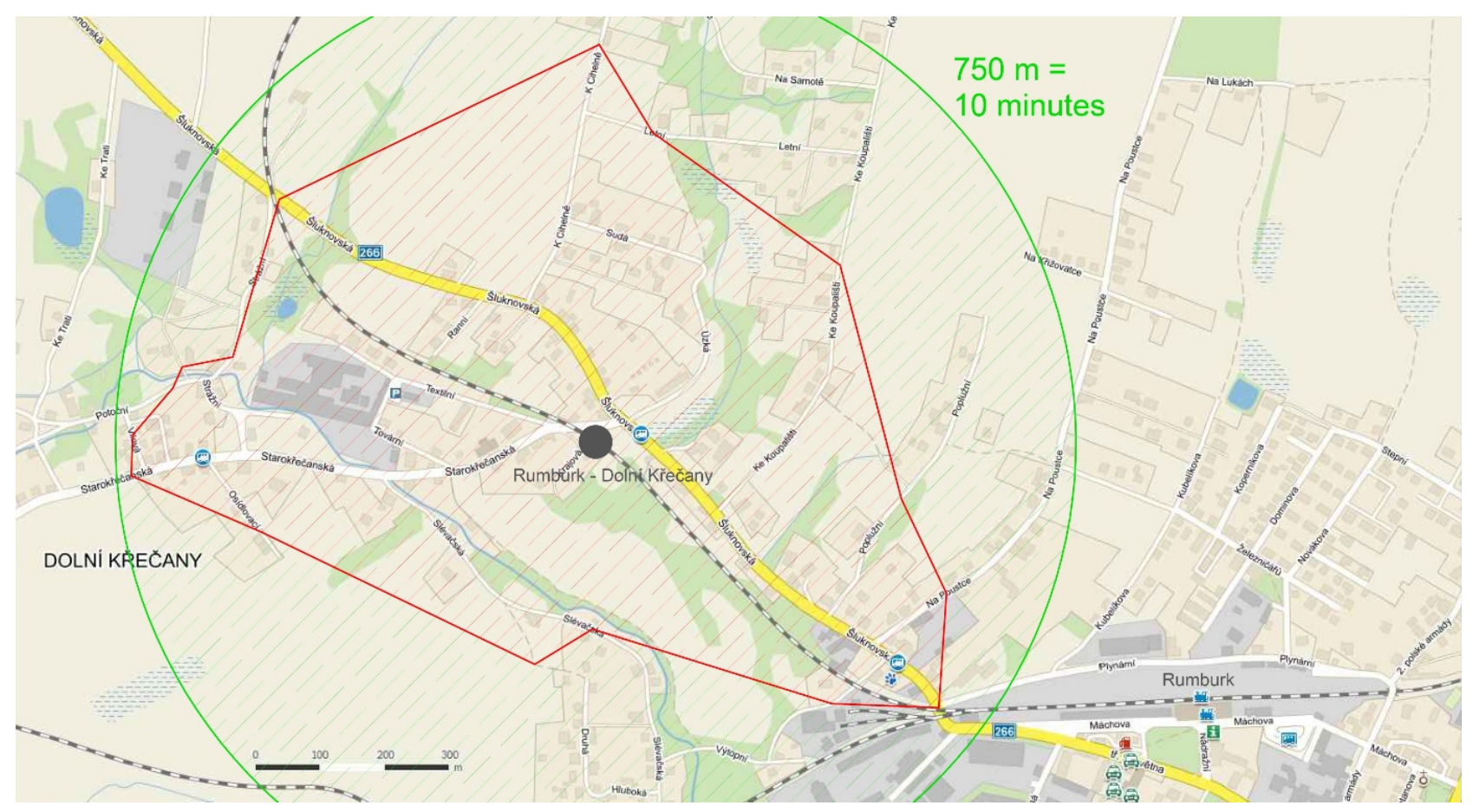

FIgURE 4. Proposed location of the new stop Rumburk-Dolní Křečany. 


\section{REFERENCES}

[1] SŽDC. Aids of theoretical graph of train running. (for researched area between years 2014 - 2016).

[2] Commuting to work and school according to summation of inhabitants, houses and flats 2011 Ústecký region [online], 2013. [cit. 2015-02-20], https://www.czso.cz/csu/czso/dojizdka-do-zamestnania-skol-podle-scitani-lidu-domu-a-bytu-2011-usteckykraj-2011-b9vyzff32a.
[3] ČSN 73 4959. Platforms and roofs of platforms of state, regional and industrial railways. ÚNMZ Praha, 2009.

[4] ČSN 73 6360-1. Geometrical characteristics of railway tracks - Part 1: Layout. ÚNMZ Praha, 2008.

[5] SŽDC s.o. Drawing tables of superstructure. (for researched area). 